\title{
Impact of the characteristics of CEO's overconfidence on the determination of incentive compensation
}

\author{
Hanen LENDA ${ }^{1 *}$, Abdelfettah BOURI ${ }^{2}$ \\ ${ }^{1}$ PhD Student in Finance and Accounting Methods University of Sfax Governance, Finance and \\ Accounting Laboratory Faculty of Economic and Management of Sfax, Tunisia \\ ${ }^{2}$ Professor in finance at the university of Sfax, Tunisia \\ *Corresponding author E-mail: hanen.lenda@gmail.com
}

\begin{abstract}
The aim of this article is to examine the impact of the characteristics of overconfident CEO's on determining incentive compensation. The sample consists of 100 US non-financial companies in the S\&P 500. The model estimation results, during the period from 2000 to 2010 , showed that overconfident executives have a significant negative impact on his incentive compensation. Furthermore, the results of multiple linear regression showed that experienced, and older CEO has a significant and positive impact on the level of incentive compensation.
\end{abstract}

Keywords: Overconfidence CEO; CEO's Age; CEO's Experience; Incentive Compensation.

\section{Introduction}

A recent literature on corporate finance has reviewed how the managers' psychological biases or characteristics affect the firms' decisions (see, for example, Bertrand and Schoar 2003, Baker, Xin, and Würgler 2012). Our emphasis is put on overconfidence, which is the people's tendency to think that they are better, compared to what they really are, in relevant characteristics, such as ability, judgment, and the prospects to ensure a successful life (optimism). While the theoretical research analyzed why overconfidence exists, (Benabou and Tirole 2002), the psychological research showed that some people, including experts, tend to be overconfident along a persistence in the degree of confidence. Actually, overconfident people tend to overestimate the expected gains of uncertain attempts, either because of the general tendency to expect good results, or because they overestimate their own efficiency in achieving success.

The managerial incentive programs are assigned, through the agency theory, a role of reconciliation between the executives and the shareholders by encouraging the former to maximize the wealth of the latter. However, due to the scandals that have shaken the financial markets since the beginning of the 2000s, observers have not failed to criticize the excessive and sometimes even the fraudulent nature of the compensation offered to public companies' senior executives while, at the same time, emphasizing the poor performance and the insolvency of some of them.

For this reason, the executives' remuneration (CEOs' Pay), which is considered partly responsible for these fiascos, became the touchstone of governance, a real Gordian knot which is hard to unpick. The issue is said to be complex, but this argument only aggravates the investors' frustration and possibly that of the large public regarding the salaries which are considered unreasonable and undeserved in many cases. In principle, being considered as governance instruments, the remuneration strategies should serve to recruit competent leaders, ensure their loyalty to the company and motivate them to have an optimal performance to promote the value creation for the benefit of all the stakeholders.

There is a lack of research on the managers' personal characteristics that affect their decision making. The only experimental study in this field is that of Libby and Rennekamp (2012), which shows that overconfident managers are more likely to perceive that the benefits associated with good practice of the result are greater than their costs. As a consequence, overconfident managers are more likely to emit good practice of the results. This observation holds a little no matter if overconfidence is induced by selfish attribution (attribution of the best performance of the task to competence or ability rather than to the luck where the task is less difficult), or it is an inherent personal trait (Libby \& Rennekamp, 2012). This experimental result confirms the archival study which shows that managers' overconfidence affects their trends to issue good practice results at a level of the market (Hribar \& Yang, 2015). Compared to the archival research, experimental studies have the advantage of providing a clean and direct measure of the managers' personal qualities and therefore, more experimental studies are needed to examine the effects of other personal attributes.

This paper tries to answer the following research question: what is the impact of overconfident leaders' characteristics on incentive compensation?

This article is organized as follows: Section 2 provides the impact of the leader's overconfidence on his incentive compensation, Section 3 presents the characteristics of overconfident leaders and their impact on incentive compensation, Section 4 focuses on the research methodology, data sources, methodology design and variables measurement, Section 5 reports the results of the empirical study and Section 6 provides the conclusion. 


\section{Impact of the leader's overconfidence on his incentive compensation}

We try to find out if overconfidence affects the structure of the CEO's compensation and of other senior executives. There is an increasingly large literature about the impact of the CEO's overconfidence on the company's policies. Overconfident CEOs are likely to overestimate the investment returns and underestimate the coming risks (Dittrich et al, 2005; Kolasinski and Malmendier and Tate, 2005 and 2008). However, we know that the nature of incentive contracts offered to overconfident managers or even companies tend to spend more precise compensation contracts, to match the manager's personality traits. Our objective is to investigate if and how overconfidence affects the incentive compensation. However, the compensation contracts would be expected to be different for overconfident managers compared to rational managers, but the nature of this difference is not obvious.

On the one hand, an overconfident manager might need lower incentives in the form of options or restricted stock given the high probability that the manager is associated with a positive result. With their highly biased view of the company's future value, a smaller participation could be sufficient to get overconfident managers make the required effort or the appropriate decision. It is also possible that a strong incentive could worsen the already overconfident manager's risk-taking. We refer to the low incentive hypothesis, which predicts a negative association between overconfidence and the proportion of incentive compensation that a manager receives. On the other hand, Gervais, Heaton and Odean, (2011), state that it may be optimal to provide overconfident CEOs with powerful incentive contracts. These authors believe that if an overconfident CEO gives a high probability of good performance, it is relatively a little expensive for the company to offer a compensation program with a strong option and stockoption intensity. Therefore, the purpose of a heavy incentive compensation contract is to enjoy the mispricing of CEO, rather than providing incentives. We call this the operating assumption, which provides a positive association between overconfidence and incentive share-based compensation received by the CEO.

The main question is therefore, to know the only reason that overconfident managers are given a powerful incentive compensation contracts to make the best use of their overestimates. Although both operating and strong incentive hypotheses predict a positive relationship between overconfidence and incentive compensation, there are two keys testable differences. First, under the exploitation hypothesis, the compensation agreement of overconfident CEO will have a neglected incentive. Therefore, a modest reduction of the option intensity has no material effect on the chief executive officer's equity or the company's value (in other words, through the decrease of the chief executive officer's equity). However, according to the hypothesis of strong incentives, a reduction of the option intensity leads to a reduction of the company's value because the options offer incentives. The second difference is about the impact of increasing the CEO's ability bargain. As it was indicated in the operating hypothesis, an increase of the CEO's negotiating power of the results increases the option intensity. The argument is that, since an overconfident CEO overestimates the options, a rise of compensation resulting from the increase of CEO's bargaining power takes the form of a higher option-based wage. However, the hypothesis predicts a strong incentive to decrease the intensity of the option; that is, in the presence of incentive conditions and a risk averse CEO, additional compensation takes a cash form.

In fact empirical tests were conducted to explore the relationship between the CEO's overconfidence and compensation to make a distinction between the three hypotheses (weak and strong incentives and exploitation). The data about the CEO's compensation were collected over the $1992 / 2011$ period and used for the purpose of creating options based on overconfidence measures. These measures are based on the idea that human capital and CEO's compensation are related to the company, which makes the CEO a little diversified. Therefore, a rational CEO deeply operates in the currency options as soon as they are acquired, which means that deeply taking options in the money indicates overconfidence. Being compatible with both hypotheses of strong incentives and exploitation, but not with the ones of low incentives, the CEO increases the options and the intensity of the shares measured by the proportion of pay, which comes from stocks and options respectively. There was evidence that overconfident CEOs still receive a greater intensity of options (and shares) in the innovative and too risky companies. The Sarbanes-Oxley Act of 2002 (SOX) was used as an exogenous to the optimal remuneration contract shock. Besides, our claim was empirically supported only if the incentive compensation, and the supervision of the board of directors are alternative governance mechanisms. For example, the SOX will make companies lower the option intensity in the remuneration contracts. However, the reduction of the option intensity is less severe for overconfident CEOs, which seems to be compatible with the exploitation hypothesis. In other words, if optionbased compensation is primarily used to exploit overconfident $\mathrm{CEO}$, it can replace the option compensation with monitoring. We complete the results at the level of the CEO with the evidence on the pay of overconfident leaders non CEOs. On setting the hypothesis, it was found that the impact of overconfidence of the leaders non CEOs on compensation is the same as it on the CEO's remuneration. In other words, it was found that overconfident executives also receive higher levels of option and action intensity than non overconfident executives. The impact of overconfidence on remuneration, in particular, does not depend on the CEO's overconfidence, in other words, regardless whether the CEO is too confident or not. Overconfident leaders receive higher levels of option and action intensity. This observation is important since it indicates the incentive compensation for the executives and executives, besides, it is driven by the same economic logic reflecting the individual traits and not only by the enterprise's level of features.

Then, some tests were conducted to distinguish the exploitation assumptions from strong incentive hypotheses. In particular, the relationship between the CEO's bargaining power and incentive compensation was first examined. Actually, the CEO's negotiating power was examined in two ways: the first way is the CEO's salary portion (Bebchuk et al., 2009) and the second is the salary change of all the staff in the same industry and to appoint a CEO. A positive relationship was found between overconfidence and the intensity of the option which forcefully argues the CEO's negotiating power, which seems to be consistent with the exploitation hypothesis, but not with the strong incentive one.

After that, the FAS 123R standard passage is used as a natural experiment to be further differentiate between the exploitation hypothesis and that of strong incentive. The FAS123R standard requires that companies report stock-based compensation at fair value in the income statement, therefore, making stock-based compensation more expensive from an accounting perspective. Hayes et al (2012) and Skantz (2012) state that the option intensity decreases after the adoption of FAS 123 standards. It is worth noting that this trend effects at the same time both overconfident and non overconfident CEOs. Moreover, since the rate of the decrease of the option intensity is similar, it is thought that the amount of cash and pay equity, as it was published in the FAS 123R standard, increases more for overconfident CEOs. which is still compatible with the exploitation hypothesis. Actually, in this case, the CEO attaches greater value to the company's options. Therefore, a reduction of option payment requires that the firm give the CEO a relatively more important compensatory increase in cash and pay equity. This conclusion about cash compensation is particularly important because it is consistent with the exploitation hypothesis and not with that of strong incentive. According to further tests, it seems that the option decrease following the use of the FAS 123R standard had no progressive significant effect on the company's value for overconfident CEOs. Nevertheless, all these elements are not definitive evidence of low incentives. Since 
the decline of the options is accompanied by subsidies granted shares, there may be a little overall effect on the CEO's incentives. H1. Overconfident leaders have a negative impact on their incentive compensation.

\section{The characteristics of overconfident leaders and their impact on incentive compensation}

Malmendier et al., (2011), showed that the leader's personal characteristics could explain the choice of business financing. On the Masulis and Mobbs (2011) showed that companies with CEOs being former internal administrators have better operational performance and show a market value on continuous growth. The evidence reported in the literature on the impact of the CEO of lines in value creation is mixed. Many studies show that the network links appear to increase the value by creating a free flow of information (Hochberg et al, 2007; Fracassi 2008). However, Guner et al. (2008) showed that the network links tend to destroy the value. On the other hand, Hwang and Kim (2009) argue that the network connections through external mandates lead to senior executive's compensation. This suggests that business leaders who are connected to a network can strengthen their control over the board of directors, which leads to a stronger deep-rooted CEO Fracassi and Tate (2012) showed that powerful leaders strengthen their position in the company by hiring directors with whom they social ties, which results in a weakened follow-up. Tenure can potentially provide CEOs with more time to align their interests with those of the Committee's report. Furthermore, full leaders can strengthen their influence on the board, which leads to an increase of the CEO power. Hill and Phan (1991) found that the regime provides general directions on time to avoid surpervision and alignment incentive mechanisms. For example, Morck et al (1988) argue that managers can be deeply rooted with relatively low property levels only under the mandate of the company's managers, the status of the founder, or his personality. Hermalin and Weisbach (1998) developed a model of power balance powers between the CEO and the other directors who predicts that the independence of the board of directors refuses a CEO during the mandate. Therefore, it can be said that executives who have more seniority are more deeply rooted, and then, have a greater influence on the board of directors and mainly on the shareholders. Consequently, permanent leaders are less likely to give way to pressure from the shareholders to make a payment in the form of share buyback programs to reduce the agency's potential costs. In fact, a negative relationship is expected to exist between the CEO's occupancy and the share buyback completion rate. However, if the CEO's confidence increases with seniority (as in Yim 2013), a positive relationship is expected to exist. As a result, the CEO's occupation variable, which is the difference between the starting date of the CEO, and the date of the takeover announcement expressed in years, is included.

The CEO's age may have a significant impact on the decision making since younger people may be more willing to take risks However, the experience grows with age, which enables the leaders to take more risks, but moderately. Evidence suggests that the risk aversion and age are not linear. In fact, personal risk aversion tends to increase with age up to 70, then, declines (Shefrin 2002). Moreover, Agarwal and all. (2008) assessed the situation by suggesting that the sophistication of the financial decisions varies with age. Yim (2013) showed that the CEO's age is positively linked to the acquisition behavior. As a result, the age variable can be included in our analysis to check if highly ranked executives are more likely to keep their commitments and complete the buyback program. Actually, the CEO's age is the difference between his date of birth and the year of the announcement of the takeover, expressed in years. In addition, we use the proxy of the experience with the CEO, i.e. the number of enterprises for which the CEO worked as Director until the moment of the announcement of the takeover. Thus, we support that the leaders want to maintain their reputation, if the company, and specifically, the CEO, is credible and keeps his promise making a payment in the form of share repurchase programs.

Moreover, we examined whether the CEO's education has an impact on the share buyback. Chevalier and Ellison (1999) found out that fund managers having a master's degree in business (MBA), tend to take more systematic risks. Therefore, it is worth evaluating the impact of the CEO's education on the business education variable, which is a dummy variable equal to 1 if the $\mathrm{CEO}$ has received a business education and zero otherwise. Besides, the highest statement variable can be included, which is a model equal to 1 if the CEO has a master's degree or higher. We have previously investigated whether pursuing a business-oriented career has an impact on the fulfillment of a company's professional or non-professional buyback is a dummy variable equal to 1 if the CEO has pursued a job -oriented career.

Barber and Odean (2001) suggest that men tend to be more confident than women. Therefore, we control the CEO's gender, which is a dummy variable with the value of 1 if the CEO is a man and zero otherwise. Moreover, the "founder" dummy variable is included, which takes the value 1 if the CEO is the founder of the company, and zero otherwise. We also include the 'internal' dummy variable, which takes the value 1 if the CEO has been internally appointed and zero otherwise. Finally, since our study is about the U K companies, the CEO's nationality is considered, which is a dummy variable having a value of 1 if the CEO is a British citizen and zero otherwise

Hackbarth (2008) developed a model through which the managers buy shares when the directors consider that their funds are undervalued. Ben-David and al. (2013) used the managers' demographic profiles to check whether some characteristics are associated with overconfidence. More particularly, researchers tested whether age, experience, education and equality are related to overconfidence. Actually, they a link with overconfidence in several of the company's decisions enterprise, such as investment and financing decisions. Moreover, researchers proposed that overconfident leaders undertake more share buybacks, which makes us propose the following hypothesis:

$\mathrm{H} 2$. Overconfident young leaders have a significant impact on the determination of their incentive compensation.

H3. The overconfident leaders' experience has a significant impact on the determination of their incentive compensation.

\section{Research methodology}

\subsection{Sampling and data collection}

Conducting a research study is an important task in the way that the researcher is called for the development of some objective and neutral qualities as well as a sense of analysis and synthesis by exploiting data and theoretical and empirical analyses. For this reason, we followed some successive and complementary steps to develop significant correlations and draw interesting conclusions. The approach applied in this study is counterfactual. This section is important because it stresses the measurement of the study variables, the descriptive statistics and the different models to be estimated. It consists in setting some empirical models to test the theoretical approach. This step requires the definition of the study sample, the definition and measurement of variables to explain and explanatory. In this chapter, we set the methodological approach of this study.

\subsection{Data source about US companies}

The list of selected US companies consists of a random sample of 100 non-financial companies of the S\&P 500 index. To collect the data, an Edgarscan database containing all the documents filed by the companies with the SEC is used. This base is used mainly for the data collection about the executives' compensation structure (bonuses, salaries, exercised/not exercised options etc.). Governance and financial information circulars are available at the Cor- 
porate Library base that includes a data panel of more than 1500 U.S. firms.

\subsection{Measurements of the study variables}

\subsubsection{The variable to be explained: the executives' incentive compensation}

Several empirical studies showed the effect of the incentive plans on the executives' discretionary behavior in the field of accounting practices. Johnson and al. $(2003,2009)$ found a positive and significant relationship between the American leaders' deferred compensation and the probability of fraud in the financial statements of the fiscal years 1992-2005. Their study focuses on a group of 87 fraudulent companies tracked by the SEC for Accounting and Auditing Enforcement Releases (AAERs) and a comparable group of companies of control. The univariate analyses and the logistic tests in conditional contingent models (conditional logistic regression) show that executives committing fraud cash are, on average, 54\% more on their portfolios of options and actions relatively to their against parts of the control group. The authors also showed that in the presence of the attributes of good governance, differences in earnings decreased by $4 \%$. Erickson et al. (2006) confirmed this relationship on a larger sample of companies. Besides, Harris, Bromiley (2007) joined them. Kedia and Philippon (2009) apply a similar modeling combined with empirical validation on a set of 845 fraudulent companies, and a group of 845 control companies observed between 1991 and 2003. Their results back the idea that leaders' incentive contracts affect the practices of accounting manipulation. The same results are backed by Howell (2007) in the Canadian context.

Our assumptions are concerned with the latitude that leaders can express on the occasion of their incentive compensation towards the accounting choices of getting ownerships and acquiring power. Cianci and al. (2011) proposed a measure of incentive compensation of the executive directors which, in itself, reflects this power. This measure expresses the dominance of these leaders on the process of determination and distribution of incentive plans. In fact, it is a measure approximated by the relative difference between the overall remuneration of the best-paid leader (CEO) and the one of his predecessor in the remuneration scale. We adopt this measure to use as a proxy for incentive compensation. In common with Cianci and al., (2011), we can deduce a ratio of the incentive compensation as follows:

Incentive compensation ratio $=(C E O$ 's overall compensation - the second manager's overall remuneration) / CEO's overall remuneration.

\subsubsection{Explanatory variables}

\subsubsection{CEO overconfidence}

The great difficulty in the accounting work dealing with the behavioral approach of overconfident executives is the identification of a relevant and operational measure of optimism and overconfidence. Two different approaches help measure this bias (Malmendier and Tate, 2005b); the first approach, which is said to be external, is the analysis of the leader's perception and description by third parties, such as the financial press. It consists in collecting representations of press articles about the leaders. A leader is classified overconfident if the words characterizing him are more frequent than those characterizing an under confident leader (cautious, conservative, not confident, etc.). The second is an internal bias approach, which refers to the preferences revealed by the leader himself through his answers to a questionnaire, the exercise of the stock options, his degree of exposure to idiosyncratic risk, or through his relative compensation.

As part of the work, the moment of the stock options is used as estimators of overconfidence. Malmendier and Tate's measurement is based on the late exercise of the stock-options and the purchases of the company's shares. In fact, overconfidence leads the leader to overestimate the value of the firm he runs as well as its investment prospects. As a result, he will tend to retain his options and acquire shares. This type of behavior reflects overconfidence more than optimism or other behavioral biases, because it explicitly refers to risk underestimation for a non-diversified leader. Three measures are therefore developed by Malmendier and Tate (2005a).

The Holder 67 measurement focuses on the exercise behavior during the year following the legal compulsory retention period (in order to compare options which have different durations). Having set a rational level of exercise (using Hall and Murphy's methodology, 2002), which corresponds to an option of $67 \%$ in the currency, the leaders who are considered overconfident are those who have not, at least twice, exercised more than this threshold.

Stock options are devoted to give beneficiaries the right to buy or subscribe for their companies' shares. This compensation component makes the leaders' wealth an increasing and unlimited function of the stock prices. However, the stock option simple allocation is not conducive to the result management. Actually, the beneficiaries' wealth depends on the difference between the price fixed by the stock option plan (the exercise price) and the share value of the exercise of the said plan. In turn, the share value depends on the market valuation which is based heavily on the financial reports in the assessment process.

On the other hand, the result management is assumed to be practiced by the leaders during the publication of the financial statements prior to the exercise of the stock options in order to affect stock prices. In our research, overconfidence measurement in connection with remuneration is operationalized through "the stock option exercise" (EXSKOP). This approach, which was adopted by Malmendier et al. (2011), is operationalized by a binary variable which equal to 1 if the leaders exercise their stock options, and 0 , otherwise.

\subsubsection{The CEO's age}

The CEO's age can have a significant impact on the decisionmaking process since younger leaders may be more inclined to take risks. However, experience develops with age, which enables managers to moderately take more risks, but in moderation. Empirical evidence suggests that risk aversion and age are not linear, then personal aversion to risk tends to increase until the age of 70 , after that it drops (Shefrin, 2002) On the other hand, Agarwal et al. (2008), after analyzing the situation, suggested that the complexity of the financial decisions varies with age. Yim (2013) stated that the leader's age was positively related to the behavior of the acquisition. Therefore, our analysis includes the age variable to check if senior executives are more likely to stick to their commitments and then finish the buyback program. In this study, the age of the chief executive officer (CEO) or the operating officer is measured using a continuous variable (in number of years). This measure was adopted by previous studies (Paquerot, 1996; Rose and Shepard, 1994; Barker and Mueller, 2002; Ghosh et al, 2007).

\subsubsection{The CEO's experience}

Senior managers with their expertise and cognitive and behavioral patterns based primarily on their professional experiences are more likely to identify problems and seek additional information in the same functional area to produce more effective decisions (Hambrick and Mason 1984 Fredrickson 1985 Walsh 1988 Hitt and Tyler 1991). Furthermore, these managers are more likely to understand the role of financial information by reducing the information asymmetry between the companies and investors (Matsunaga and Yeung, 2008) and helping the financial experts to evaluate the company (Hutton and Stocken, 2009). Being responsible for the publication of results, these managers have to personally certify the accuracy and completeness of the financial information published by the company. The financial expertise and experience enable the $\mathrm{CEO}$ to implement accounting disclosure policies and better monitor the companies. In fact, compared to 
their financially inexperienced counterparts, financially experienced managers provide guidance on the most accurate results (Matsunaga and Yeung 2008) and are therefore, less likely to manipulate the results.

On the basis of the slightly broader definition of financial experience given by Matsunaga and Yeung, a financially experienced $\mathrm{CEO}$ is someone who served as chief financial officer or in another high administrative position in finance or accounting for several years. The leader's seniority is evaluated on the basis of the period he spends in his position. Some authors state that a long period of function implies deep rootedness and leads to the leader's increased power as he had ample time to build relationships with his different partners and therefore, consolidate his negotiating power and extend his supremacy. In this study, this variable is measured by the length of the office term of the leader (CEO or DG) in his position (in years). This measure was adopted by previous studies (Berger et al., 1997; Rose and Shepard, 1994; Ryan and Wiggins, 2002; Barker and Mueller, 2002).

4.3.3. The variables related to the company's characteristics: Selection and measurement of the control variable

The leader's profile characteristics are not the only factors that affect his compensation. Actually, there are other factors that can explain it. For this reason, control variables, such as the activity sector, the firm's size, and the debt ratio, could be retained. Regarding the company's financial and economic characteristics, some variables, which are used in similar studies, are taken into account since they might explain the effects of the company's financial and economic peculiarities on the magnitude and design of incentive pay.

\subsubsection{The activity sector (SECT)}

These companies are divided into two groups according to a classification made by the Organization for Economic Cooperation and Development (OECD, quoted by Tylecote and Ramirez, 2006). The first group includes the companies that belong to the high-technology sector, whereas the second involves the traditional sector. According to the OECD, high-tech sectors are defined on the basis of their high intensity in $\mathrm{R} \& \mathrm{D}$, for instance, pharmaceutical and medical industries, telecommunication and information technology, whereas, medium and low technological sectors are characterized by lower R \& D intensity rates. Actually, they include mainly electric and electronic sectors, mechanical engineering, chemical products, excepting pharmaceuticals products, and the food sector. As a consequence, this variable takes value 1 if the firm belongs to the high-tech sector and 0 if it belongs to the traditional sector.

\subsubsection{The company's size}

To measure the company's size, three indicators can be identified The first is the number of employees; the second is the sales volume, and the third is the total assets. In fact, the total assets are used as a measurement of this variable. However, to compensate for the variability of results due to the presence of companies whose sizes are widely different, that is to say, to reduce the amplitude of the size variable for large companies and the heteroscedasticity and the spreading that may result from some extreme points, we will use the natural log of the companies' total assets. This measure was used by Fama and French (1995).

\subsubsection{Company's indebtedness}

Funding is the problem that any company has to control. In this context, each company must have a balanced financial structure which is somewhat a more or less difficult task since choosing such a modality may positively or negatively affect the company's financial performance. A bad funding choice can lead the company to bankruptcy. The spending intensity on research and development, the company's size, its profitability and the tangible char- acteristics of its assets are considered in most studies as determinants of the companies' financed choice (Rajan and Zingales, 1995). In this regard, Titman and Wessels (1988) showed that the structure of the firm's assets affects its debt policy. The authors associated the rise of the proportion of debt with the increase of the tangible component of the assets. This can be explained by the fact that the bankruptcy cost of the companies that have a proportion of tangible assets that can serve as collateral is relatively low. However, the bankruptcy cost increases in companies that have strong components of specific assets. In this respect, these firms' leverage is normally very low. Moreover, their funding constraint in research and development is explained by their intangible nature besides the risk that characterizes them and, which results in an uncertain future value of these investments. Therefore, the most innovative companies are the least indebted.

Indebtedness is regarded as a fundamental variable in corporate finance research especially when making investment decisions. In our analysis, it is proposed that we use a purely accounting measure through the debt ratio (ENDET) calculated using the annual report: total debt / total assets (Fama and French, 1995). This measure was also used by Agrawal and Knoeber (1996), Kochhar and David (1996), Barker and Müller, (2002) and Lee and O'Neill, (2003).

\subsection{The research model: The CEO's overconfidence and his incentive compensation}

To test the impact of the CEO's overconfidence on the level of incentive compensation in the presence of a few control variables, a multiple linear regression methods is used as a method of statistical analysis to test our hypothesis. The mathematical specification of the first model can take the following form:

$I N C C E O=\alpha_{0}+\alpha_{1} O_{V E R O C E}+\alpha_{2} E_{X P C E O}+\alpha_{3} S E C T_{i t}+\alpha_{4} S I Z E_{i t}+\alpha_{5} D E B T_{i t}+\varepsilon_{i t}$ With:

Table 1: Explanatory Variable Measurement Summary

\begin{tabular}{|c|c|c|c|}
\hline Variables & $\begin{array}{l}\text { Variables de- } \\
\text { scriptions }\end{array}$ & $\begin{array}{l}\text { Variables } \\
\text { measures }\end{array}$ & Symbols \\
\hline $\begin{array}{l}\text { The leaders' } \\
\text { overconfidence }\end{array}$ & $\begin{array}{l}\text { The CEO's over- } \\
\text { confidence and } \\
\text { the stock option } \\
\text { exercise }\end{array}$ & $\begin{array}{l}\text { The binary varia- } \\
\text { ble, which takes } \\
\text { value } 1 \text { if the } \\
\text { managers exercise } \\
\text { their stock options }\end{array}$ & OVEROCE \\
\hline The CEO's age & The CEO's age & $\begin{array}{l}\text { A continuous } \\
\text { variable in num- } \\
\text { ber of years }\end{array}$ & AGECEO \\
\hline $\begin{array}{l}\text { The CEO's } \\
\text { experience }\end{array}$ & $\begin{array}{l}\text { The duration of } \\
\text { the CEO's office } \\
\text { term }\end{array}$ & $\begin{array}{l}\text { The number of the } \\
\text { CEO's working } \\
\text { years }\end{array}$ & EXPCEO \\
\hline $\begin{array}{l}\text { Incentive com- } \\
\text { pensation }\end{array}$ & $\begin{array}{l}\text { The incentive } \\
\text { compensation } \\
\text { ratio measures } \\
\text { the CEO's com- } \\
\text { pensation }\end{array}$ & $\begin{array}{l}\text { (CEO's overall } \\
\text { compensation- } \\
\text { total compensa- } \\
\text { tion of the second } \\
\text { leader) / total } \\
\text { compensation of } \\
\text { CEO }\end{array}$ & INCCEO \\
\hline Activity sector & $\begin{array}{l}\text { The firm's be- } \\
\text { longing to the } \\
\text { activity sector }\end{array}$ & $\begin{array}{l}\text { Binary variable is } \\
\text { equal to } 1 \text { if the } \\
\text { firm belongs to } \\
\text { the high-tech } \\
\text { sector and } 0 \text { it } \\
\text { belongs to the } \\
\text { traditional sector }\end{array}$ & SECT \\
\hline The firm's size & $\begin{array}{l}\text { The firm's size is } \\
\text { measured with } \\
\text { the natural log of } \\
\text { the company's } \\
\text { total assets }\end{array}$ & LN (total assets) & SIZE \\
\hline $\begin{array}{l}\text { The firm's } \\
\text { indebtedness }\end{array}$ & $\begin{array}{l}\text { The firm's in- } \\
\text { debtedness level } \\
\text { is measured with } \\
\text { the indebtedness } \\
\text { ratio }\end{array}$ & $\begin{array}{l}\text { Total financial } \\
\text { debt/total assets }\end{array}$ & DEBT \\
\hline
\end{tabular}


The series of variables used in our model have two dimensions: one for individuals (the sample selected companies) and another for the time. They are indicated by the indices i and $t$, respectively. This is then about panel data related to endogenous variables (incentive compensation) and exogenous variables presented by the leader's overconfidence, his age, his experience as well as by the control variables, such as the company's activity sector, its size and its indebtedness level. In this context, our focus on the multiple linear regression estimation. In fact, the endogenous variable is assessed on the basis of the exogenous and the control variables.

\subsection{Descriptive statistics of the model variables}

The descriptive statistics gives a picture or a data description by examining the average, the standard deviation and the maximum and minimum value of the used variables (Ghozali, 2005). It consists in performing a preliminary analysis of the sample and of the research variables. Through this analysis, our first task is to identify the trend of each variable (univariate analysis), then, a bivariate analysis so as to identify the relationship between the explanatory variables.

\subsubsection{A univariate analysis of the variables}

Table 1 presents and synthesizes the descriptive statistics of the variables retained in the model. It also reports in particular the mean, the standard deviation, and the minimum and maximum value. First, we will analyze these statistics at the level of endogenous variables, then the tendency of the exogenous variable, and finally, the control variables. The leaders are averagely aged 57 and have an average 6-year experience in the post of a chief executive officer (CEO). Over the study period, the American executive officers receive on average 3,378 million dollars in the form of contingent compensation, which corresponds to an average incentive of $65.7 \%$. This value is likely to be similar to that found by Chourou et al. (2008). for a sample of 196 companies of the S\&P/TSX300 index (0.73) and that of Cormier et al. (2006) for 98 companies of TSE100 (0.62) but, by simply considering the stock option component. However, according to Elloumi and Gueyié (2001). This ratio is worth only $0,4487$.

Table 2: Descriptive Statistics of the Model Variables

\begin{tabular}{lllll}
\hline & Average & $\begin{array}{l}\text { Standard devia- } \\
\text { tion }\end{array}$ & Minimum & Maximum \\
\hline ceoinct & 0.131 & 0.095 & .002 & 1.565 \\
Ceoovc & 0.748 & 0.434 & 0 & 1 \\
ceoage & 57.532 & 5.827 & 50 & 70 \\
ceoexp & 6.0112 & 2.348 & 1 & 10 \\
debt & 0.2185 & 0.233 & 0.015 & 1.651 \\
Logsize & 13.40 & 3.540 & 0 & 27.885 \\
Sect & 0.333 & 0.471 & 0 & 1 \\
\hline
\end{tabular}

Note: this table rapport mean, std dev, min and max of variabe used in this paper where the sample includes data on 100 non fiancial companies from U.S market over the period 2000-2010. ceoinct represent the incentive compensation, ceoovc represent the ceo overconfidence, ceoage represent the age of ceo, ceoexp represent the ceo experience, debt represent the firm's indebtedness, logsize is the size of the firms, and finally sect represent activity sector.

\subsubsection{Bivariate analysis of the independent variables: residual and linearity normality test}

- Autocorrelation test between residues: an autocorrelation problem is manifested by the fact that the variance/ covariance matrix of the error terms is not diagonal. In other words, the error terms of the various observations are not independent. Ghozali (2013) states that the residual normality tests are used especially for small samples, therefore, we can ignore them for large samples. Moreover, the autocorrelation problem between residues does not arise in our empirical studies since the selected sample consists only of 100 non-financial companies of the S\&P 500 index.
- Multi-colinearity test between the explanatory variables in the model: the aim of multi-colinearity test is to check if the regression model shows a correlation between the independent variables. A good regression model should have no correlation between the independent variables. Moreover, if the independent variables are highly correlated, then they are not orthogonal. One way to detect the existence or the absence of mult-colinearity between the independent variables is to refer to the correlation matrix. Regarding the existence or absence of a multicolinearity in the regression model, Ghozali, (2013), states that it exists if and only if the correlation between the independent variables is greater than $90 \%$. According to the correlation matrix (see the table below), the correlation coefficients between the independent variables are always lower than Ghozali's(2013) (0.9) coefficient. This makes us conclude that the bivariate multicollinearity problem proves to be perfectly absent in the whole model to be tested. In fact, the correlation between all the independent variables does not exceed the maximum evoked by Ghozali (2013). The correlation coefficients between the various explanatory variables used in the model are shown in Table 3.

Table 3: Analysis of the Linear Correlations of the First Model Variables

\begin{tabular}{|c|c|c|c|c|c|c|}
\hline & ceoovc & Ceoage & Ceoexp & debt & Logsize & Sect \\
\hline Ceoovc & 1 & & & & & \\
\hline Ceoage & 0.0165 & 1 & & & & \\
\hline Ceoexp & 0.0391 & 0.1466 & 1 & & & \\
\hline Debt & 0.0621 & 0.0079 & 0.0020 & 1 & & \\
\hline Logsize & 0.0664 & 0.0495 & 0.0496 & 0.0012 & 1 & \\
\hline Sect & - & 0.0426 & 0.0124 & 0.0008 & -0.0455 & 1 \\
\hline
\end{tabular}

Note: This table represent correlations between variables used in this paper.

\subsection{Multivariate analysis: results and interpretations}

After conducting a descriptive study dealing with the sample characteristics and the functional relationships between the variables, a multi-varied analysis was carried out through which the focus is on the methodological tools that assure the testing of the hypothesis of our study by estimating the multiple regression models.

\subsubsection{Econometric tests applied to the model}

To choose the most appropriate estimation method, the four-model regression should be preceded by the following econometric tests

INCCEO $_{i t}=\alpha_{0}+\alpha_{1}$ OVERCEO $_{i t}+\alpha_{2}$ EXPCEO $_{i t}+\alpha_{3}$ SECT $_{i t}+\alpha_{4}$ SIZE $_{i t}+\alpha_{5}$ DEBT $_{i t}+\varepsilon_{i t}$

- The homogeneity test: this is a specification test that follows Fisher's statistics and intended to confirm the existence or non-specific effects. The existence of an effect leads us to choose between the fixed or random effect methods;

- The Hausman test: this is a specification test that follows the chi-squared statistics. It is used to distinguish between the fixed and random effects;

The heteroscedasticity test: it follows the chi-squared statistics. If we have a fixed effect, the, heteroscedasticity will be tested by the means of Wald's modified test, however, when we have a random effect, the Breush-Pagan test will be carried out.

- The tests of coefficient significance after our model is specified. During the final estimation of our model, our focus will be on whether each explanatory variable has a significant effect on the endogenous variable.

The features of every test applied to our model is presented as follows

Homogeneity test

Heterogeneity or individual effects.

Greene (2005) states that the heterogeneity between the units (or individuals) is the core issue in the analysis of the panel data. Actually, the main benefit of a panel data sample in relation to a 
cross-section is that it enables the researcher to study the differences in the individual behavior. As a consequence, when a panel data sample is used, the first thing that should be checked is the homogeneous or heterogeneous specification of the data generating process. In econometric terms, this consists in testing the model coefficient equality examined in the individual dimension.

$$
\mathrm{Yit}=\alpha+\beta \mathrm{Xit}+\mu \mathrm{i}+\varepsilon \mathrm{it}
$$

Avec:

- $\alpha$ is a constant

- X represents the vector of the explanatory variables

- $\mu_{i}$ : represents the individual effet

$-\varepsilon$ it the error term

Therefore, the $\mu_{\mathrm{i}}$ term in the previous equation represents the individual effect or the heterogeneity between the firms. This individual effect can be either fixed or random. As a consequence, equation (1) is said to be either o fixed or random effect model, depending on the nature of the individual effects.

\section{- $\quad$ Testing the existence of individual effects}

On a sample of panel data, it is appropriate to test the significance of the group or individual effects. To check the relevance of the individual effects in the model, we just have to test the null hypothesis H0: $u i=0$ in the above regression. The STATA software makes it possible to test the significance of the individual effect by estimating both the unconstrained model, which includes the term corresponding to the individual effect, and the constrained model in which this term is not included. Actually, this software gives us the $\mathrm{F}$ statistics and the (p-value) probability associated to it, which enable us to test the null hypothesis according to which the individual effect included in the model is not significant. A ( $p$-value) probability value less than 5\% implies the rejection of $\mathrm{H} 0$. The performance of this test on the STATA software gives the results presented in the following table:

Table 4: Testing the Existence of Individual Effects

\begin{tabular}{lll}
\hline Specification test & Result & Specific effect \\
\hline F-Statistics & $\mathrm{F}(81,814)=175.38$ & Existence of specific effect \\
Prob $>$ F & 0.000 &
\end{tabular}

Note: this table report the estimates of the probability F-statistics.

The previous table shows that the probability associated with the F-statistics makes us reject the non-relevance hypothesis of the individual effects in our data at the $1 \%$ significance level. This result confirms the presence of individual effects, which indicates the heterogeneous character of our sample. With the existence of an individual effect model, the question that arises is how these effects must be specified: should we adopt the hypothesis of fixed effects or, on the contrary, that of the random effects? The answer to this question is given in the following paragraph.

Hausman specification test

With the existence of panel data, this test is used to segregate both fixed and random effects,

In the presence of panel data, this test is used to discriminate against the fixed and random effects. It presumes that there are two types of estimators; an unbiased estimator under the (H0) null hypothesis and a biased estimator (alternative hypothesis: H1) (Hurlin, 2001).

On considering the following model

$$
y_{i t}=a_{i}+x_{i t} \beta+\varepsilon_{i t} ; \text { Avec: } \mathrm{i}=1 \ldots \mathrm{N} ; \mathrm{t}=1 \ldots \mathrm{T}
$$

The tested hypothesis is about the correlation between the individual effects and the explanatory variables

$$
\begin{aligned}
& H_{0}: E\left(a_{i} / x_{i t}\right)=0 \\
& H_{1}: E\left(a_{i} / x_{i t}\right) \neq 0
\end{aligned} ; \text { Avec: } \mathrm{i}=1 \ldots \mathrm{N} ; \mathrm{t}=1 \ldots \mathrm{T}
$$

The $\chi^{2}$ statistics is given by:

$$
H=\hat{J}^{\prime}[V(\hat{J})]^{-1} \hat{J} \sim \chi^{2}(K-1) ; \hat{J}=\hat{\beta}_{M C G}-\hat{\beta}_{W}
$$

With $\mathrm{k}$ as the number of the explanatory variables

The Hausman test performed on the parameters of M1model using the STATA 11 data analysis software gave a Chi-squared value of 69.47 and a probability of 0.000 . These results, which suggest the existence of a fixed effect in our model, are summarized in the following table:

Table 5: Hausman Test Related to M1 Model of Study

\begin{tabular}{lllll}
\hline Model & DL : $\mathrm{K}^{*}$ & $\chi 2(\mathrm{k})$ à $1 \%$ & $\mathrm{p}$-value & $\mathrm{EF} / \mathrm{EA}^{* *}$ \\
\hline Model & 6 & $(69.47)$ & 0.000 & $\mathrm{EF}$ \\
\hline
\end{tabular}

Note: this table reports the estimates of Hausman test of M1.

${ }^{*} \mathrm{~K}$ : Number of the explanatory variables

${ }^{* *} \mathrm{EF}$ : Fixed effects

If $\chi^{2}(\mathrm{k})>\chi^{2}$ (Hausman): this implies the existence of a random effect (EA).

If $\chi^{2}(\mathrm{k})>\chi^{2}$ (Hausman): this implies the existence of a fixed effect (EA).

Heteroscedasticity test

To detect heteroscedasticity, several tests can be used to perform this task, among which we can mention the Breush-Pagan, the modified Wald and the White test. Generally, this test is designed to check if the independent variables explain the squared residual. Therefore, it can be said that there is a problem of heteroscedasticity. This test follows a chi-squared of $\mathrm{N}$ degrees of freedom. The Hausman test results showed that the model has fixed effects. Applying the Breush-Pagan test on the fixed effect model generated a Chi-squared value of 1.23 and a p-value probability of 0.13 . This shows that there is a heteroscedasticity problem in our model. The Breush-Pagan test applied on the model detected no heteroscedasticity problem because the Chi-square value is equal to 1.23 and the $\mathrm{p}$-value is equal to 0.13 . This result indicates the absence of a heteroscedasticity problem.

Table 6: Heteroscedasticity Related to Model

\begin{tabular}{lllll}
\hline Models & DL : N & $\chi 2(\mathrm{k})$ à $5 \%$ & p-value & Heteroscedasticity \\
\hline Model & 902 & 1.23 & 0.13 & Absence \\
\hline
\end{tabular}

Note: this table reports the estimates from the heteroscedasticity test.

\subsubsection{Results and estimate interpretations}

To study the impact of the leader's characteristics on his incentive compensation in the U.S. financial market, an estimation of model is carried out using a sample of US firms. For this reason, we first examine the relationship between the leader's characteristics and the level of incentive compensation in the presence of a few control variables. A negative relationship is expected to exist between the leaders' overconfidence and the incentive compensation ratio. Table 6 below summarizes the results of model estimation during the $2000 / 2010$ period.

Table 7: Results of the Model Estimation

\begin{tabular}{llll}
\hline \multirow{4}{*}{ Variables } & \multicolumn{2}{l}{ Model of study } \\
& Coeff. & t-student & p-value \\
\hline Constant & 22.421 & 9.50 & 0.000 \\
Ceoovc & -0.474 & $7.14^{* * *}$ & 0.000 \\
Ceoage & 0.137 & $3.97 * * *$ & 0.000 \\
Ceoexp & 0.205 & $2.52^{* * *}$ & 0.012 \\
Debt & -0.303 & 0.37 & 0.712 \\
Logsize & 0.050 & 1.34 & 0.405 \\
Sect & 0.017 & $5.45^{* * *}$ & 0.000 \\
adjusted $\mathrm{R}^{2}$ & 0.23 & & \\
F-statistic & 4.53 & & \\
Prob (F-stati) & 0.000 & & \\
$\mathrm{~N}$ & 902 & \\
\hline Note: This table estimate the regression coefficient, t-student test and p- \\
value of M1.
\end{tabular}


It should be noted that the objective behind carrying out the model estimation shown above is to check and validate the hypothesis suggesting the existence of a positive relationship between the leader's characteristics and the ratio of the incentive pay. The model estimation emphasizes that the adjusted R2 is about 0.23 . This result shows that the explanatory variables have contributed to the explanation of the dependent variable at the rate of $23 \%$. Therefore, the model has an acceptable explanatory power. Our results are consistent with those found by Goetzmann and Massa (2008) and Cekauskas and Liatukas (2011).

Actually, the regression coefficient of the overconfident leader variable is negative and significant $(\beta=-0.447$, t-student $=7.14$ and $p$-value $=0.000$ ). This means that any increase of the rate of overconfident executives results in a decrease of the incentive compensation ratio. This result is explained by the fact that overconfident executives tend to overestimate the firm's future results, which reflects their optimistic behavior. The negative association between the measures optimism, namely, the leaders' overconfidence and the rate of incentives in the CEO's overall remuneration, suggests that the conclusions are not explained by a higher risk and the CEO's tolerance. The results achieved by Gervais, Heaton, and Odean (2011) suggest that the effect of overconfidence on remuneration is non-monotonous.

On the other hand, according to the empirical results, the leader's experience has a positive and significant impact on the incentive compensation ratio $(\beta=0.205$, t-student $=2.52$ and $\mathrm{p}$-value $=$ 0.012). This is explained by the fact that the leader's age is an asset that can enhance his human and reputational capital, which would have consequences on his compensation ratio. Consequently, the empirical evidence showed that there is a positive association between the leader's age and the incentive compensation ratio $(\beta=0.137, \mathrm{t}$-student $=3.97$ and $\mathrm{p}$-value $=0.000)$. This result can be explained by the fact that older executives are more demanding in terms of incentive compensation.

This explanation is consistent with the negative effect of the CEO's optimism on his compensation if this optimism makes him to accept the objectives of the ex-ante returns that may appear too high in the ex-post phase. However, the same result may occur if the CEO's compensation depends on whether the company meets or not its own expected revenue. Some CEOs, who seem to be optimistic, can receive ex-post salaries. Rosa (2008) studied the effects that management overconfidence can have on incentive contracts. In fact, an overconfident agent who assesses the contingent success claims more than a rational agent because he often believes he will succeed more than he can actually do. On the other hand, if an agent is too confident about his influence on the success chances, weaker incentives are enough to dive him make some effort. A document with an accounting subject shows that the CEO's overconfidence increases the probability that the company will commit financial information fraud (Schrand and Zechman, 2010). Van den Steen (2005) showed that managers who have strong belief about the right of acting, such as overconfidence, attract employees who share the same belief.

This conformity of beliefs assigns the management to the company and decreases the need for coordination. However, it also shows that overconfidence may cause slow learning. Finally, Gervais and al. (2003) showed that overconfidence overcomes the agency and overconfident managers' pay problems as if they were rational in hindering the shareholders.

This can be explained by the fact that wealth is needlessly transferred, which leads managers to take more risks than it should be for the shareholders' benefit. This might imply that if managers are too confident and their shareholders can observe this, the expensive compensation schemes are unnecessary, which is beneficial for the company (Sudarsanam Furthermore, the regression coefficients of the control variables are not similar. Therefore, the activity sector has a positive and significant effect at the threshold of $1 \%(\beta=0.017$, t-student $=5.45$ and $p$-value $=0.000)$. Regarding the company's indebtedness variable, the results obtained through the estimation of M1 model revealed a negative but nonsignificant correlation between the incentive compensation ratio and this variable $(\beta=-0.303$, t-student $=0.37$ and $p$-value $=0.712)$. This result shows that company's indebtedness is not important in terms of the identification of the incentive compensation rate. Finally, regarding the company's size variable, the estimated coefficient is positive but not significant $(\beta=0.050$, $\mathrm{t}$-student $=1.34$ and $p$-value $=0.405$ ). This shows that this variable has no impact on the explanation of our model.

\section{Conclusion}

A document with an accounting subject shows that the CEO's overconfidence increases the probability that the company will commit financial information fraud (Schrand and Zechman, 2010). Van den Steen (2005) showed that managers who have strong belief about the right of acting, such as overconfidence, attract employees who share the same belief. This conformity of beliefs assigns the management to the company and decreases the need for coordination. However, it also shows that overconfidence may cause slow learning. Finally, Gervais and al. (2003) showed that overconfidence overcomes the agency and overconfident managers' pay problems as if they were rational in hindering the shareholders. This can be explained by the fact that wealth is needlessly transferred, which leads managers to take more risks than it should for the shareholders' benefit. This might imply that if managers are too confident and the shareholders can observe this, the expensive compensation schemes are unnecessary, which is beneficial for the company (Sudarsanam).

The analysis revealed that CEO's overconfidence negatively affects the incentive compensation whereas his age and experience positively affect it. On the other hand, debt and size had no significant impact on incentive compensation. Moreover, statistical tests showed that the control variables (size, debt) have had no significant impact on incentive compensation but the sector variable had a significant impact.We will appeal to current research on incentive compensation of CEOs from the perspective of the implications of behavioral finance.This paper proposes a set of answers to the impact of CEOs overconfidence on incentive compensation in the American context. Thus, this study attempts to provide explanations and managerial solutions for the American companies suffering from a lack of incentive compensation.

\section{References}

[1] Aggarwal, R.K. 2008. Executive compensation and incentives, in Handbook of Corporate Finance: Empirical Corporate Finance. Elsevier/North-Holland, Amsterdam. https://doi.org/10.1016/B978 0-444-53265-7.50009-3.

[2] Agrawal, A., \& Knoeber, C. R. (1996). Firm performance and mechanisms to control agency problems between managers and shareholders. Journal of financial and quantitative analysis, 31(03), 377-397. https://doi.org/10.2307/2331397.

[3] Barker III, V. L., \& Mueller, G. C. (2002). CEO characteristics and firm R\&D spending. Management Science, 48(6), 782-801. https://doi.org/10.1287/mnsc.48.6.782.187.

[4] Bebchuk, L., Cohen, A., Ferrell, A., 2009. What matters in corporate governance? Review of Financial Studies 22 , 783-827. https://doi.org/10.1093/rfs/hhn099.

[5] Bellemare, C., Shearer, B., 2010. Sorting, incentives and risk preferences: evidence from a field experiment. Economics Letters 108 https://doi.org/10.1016/j.econlet.2010.06.010

[6] Bénabou, R., Tirole, J., 2002. Self-confidence and personal motivation. Quarterly Journal of Economics 117, 871-915. https://doi.org/10.1162/003355302760193913.

[7] Ben-David, I., Graham, J., Harvey, C., 2013. Managerial miscalibration.

[8] Benjamin E. Hermalin and Michael S. Weisbach, Endogenously Chosen Boards of Directors and Their Monitoring of the CEO, The American Economic Review, Vol. 88, No. 1 (Mar., 1998), pp. 96118

[9] Berger, A. N., \& Mester, L. J. (1997). Inside the black box: What explains differences in the efficiencies of financial institu- 
tions?. Journal of banking \& finance, 21(7), 895-947. https://doi.org/10.1016/S0378-4266(97)00010-1.

[10] Bergman, N., Jenter, D., 2007. Employee sentiment and stock option compensation. Journal of Financial Economics 84, 667-712. https://doi.org/10.1016/j.jfineco.2006.01.008.

[11] Bertrand, M., Schoar, A., 2003. Managing with style: the effect of managers on firm policies. Quarterly Journal of Economics

118

$1169-1208$ https://doi.org/10.1162/003355303322552775.

[12] Bettis, C., Bizjak, J., Lemmon, M., 2001. Managerial ownership, incentive contracting, and the use of zero-cost collars and equity swaps by corporate insiders. Journal of Financial and Quantitative Analysis 36, 345-370. https://doi.org/10.2307/2676287.

[13] Brad M. Barber and Terrance Odean, Boys Will be Boys: Gender, Overconfidence, and Common Stock Investment, The Quarterly Journal of Economics, Vol. 116, No. 1 (Feb., 2001), pp. 261-292. https://doi.org/10.1162/003355301556400.

[14] Brown, R., Sarma, N., 2007. CEO overconfidence, CEO dominance and corporate acquisitions. Journal of Economics and Business 59, 358-379. https://doi.org/10.1016/j.jeconbus.2007.04.002.

[15] Byoung-Hyoun Hwang, Seoyoung Kim, It pays to have friends, Journal of Financial Economics 93 (2009) 138-158. https://doi.org/10.1016/i.jfineco.2008.07.005

[16] Camerer, C., Lovallo, D., 1999. Overconfidence and excess entry: an experimental approach. American Economic Review 89, 306-318. https://doi.org/10.1257/aer.89.1.306.

[17] Campbell, C., Gallmeyer, M., Johnson, S., Rutherford, J., Stanley, B., 2011. CEO optimism and forced turnover. Journal of Financial Economics 101, 695-712. https://doi.org/10.1016/j.jfineco.2011.03.004.

[18] Čekauskas, K., \& Liatukas, V. (2011). Behavioural Biases of the Disposition Effect.

[19] Cesare Fracassi and Geoffrey Tate, External Networking and Internal Firm Governance, the Journal of finance • vol. lxvii, no. 1 • february 2012.

[20] Cesare Fracassi, Corporate Finance Policies and Social Networks, 2008, Job market paper.

[21] Charles W. L. Hill and, Phillip Phan, Ceo Tenure As a Determinant of Ceo Pay ACAD MANAGE J September 1, 1991 34:3707-717.

[22] Chourou, L., Abaoub, E., \& Saadi, S. (2008). The economic determinants of CEO stock option compensation. Journal of Multinational Financial Management, 18(1), 61-77. https://doi.org/10.1016/j.mulfin.2007.05.001.

[23] Cianci, A. M., Fernando, G. D., \& Werner, E. M. (2011). The differential CEO dominance-compensation and corporate governance-compensation relations: Pre-and post-SOX. Advances in Accounting, 27(2) https://doi.org/10.1016/j.adiac.2011.06.001

[24] Cooper, A., Woo, C., Dunkelberg, W., 1988. Entrepreneurs' perceived chances for success. Journal of Business Venturing 3, 97-108. https://doi.org/10.1016/08839026(88)90020-1.

[25] Cormier, D., Landry, S., \& Magnan, M. (2006). Gestion du résultat ou optimisation fiscale? Evaluation des octrois d'options d'achat d'actions selon le contexte de gouvernance actionnariale. Canadian Journal of Administrative Sciences/Revue Canadienne des Sciences de l'Administration, 23(2), 153-168. https://doi.org/10.1111/j.19364490.2006.tb00687.x.

[26] DA SILVA ROSA, Raymond et Durand, Robert B. The role of salience in portfolio formation. Pacific-Basin Finance Journal, 2008, vol. 16 , no 1 , p. $78-94$.

[27] David Hirshleifer, Angie Low, and Siew Hong Teoh," Are Overconfident CEOs Better Innovators?", The Journal of Finance • VOL. LXVII, NO. 4 • August 2012.

[28] De Angelis, D., Grinstein, Y., 2012. Pay for the right performance. Unpublished working paper. Rice University and Cornell University

[29] Dittrich, D.A.V., Guth, W., Maciejovsky, B. 2005. Overconfidence in investment decisions: An experimental approach. European Journal of Finance, 11(6), 471-491. https://doi.org/10.1080/1351847042000255643.

[30] Dohmen, T., Falk, A., 2011. Performance pay and multidimensional sorting: productivity, preferences, and gender. American Economic Review 101, 556-590. https://doi.org/10.1257/aer.101.2.556.

[31] Doukas, J., Petmezas, D., 2007. Acquisitions, overconfident managers and self-attribution bias. European Finan- cial Management 13, 531-577. https://doi.org/10.1111/j.1468036X.2007.00371.x.

[32] Elloumi, F., \& Gueyie, J. P. (2001). Financial distress and corporate governance: an empirical analysis. Corporate Governance: The international journal of business in society, 1(1), 15-23. https://doi.org/10.1108/14720700110389548.

[33] Englmaier, F., 2007. A strategic rationale for having overoptimistic managers. Unpublished working paper. LudwigMaximilians- University Munich.

[34] Englmaier, F., 2010. Managerial optimism and investment choice. Man- agerial and Decision Economics 31, 303 310. https://doi.org/10.1002/mde.1498.

[35] Englmaier, F., 2011. Commitment in R\&D tournaments via strategic delegation to overoptimistic managers. Managerial and Decision Economics 32, 63-69. https://doi.org/10.1002/mde.1518.

[36] Fama, E. F., \& French, K. R. (1995). Size and book-to-market factors in earnings and returns. The Journal of Finance, 50(1), 131155. https://doi.org/10.1111/j.1540-6261.1995.tb05169.x.

[37] Fathi Elloumi, Jean-Pierre Gueyié, (2001) "Financial distress and corporate governance: an empirical analysis", Corporate Governance: The international journal of business in society, Vol. 1 Iss: 1, pp.15 - 23. https://doi.org/10.1108/14720700110389548.

[38] Feng, Z., Ghosh, C., \& Sirmans, C. F. (2007). CEO involvement in director selection: implications for REIT dividend policy. The Journal of Real Estate Finance and Economics, 35(4), 385-410. https://doi.org/10.1007/s11146-007-9065-3.

[39] Fredrickson, J. W. (1985). Effects of decision motive and organizational performance level on strategic decision processes. Academy of Management journal, 28(4), 821-843. https://doi.org/10.2307/256239.

[40] Gao, H., 2010. Optimal compensation contracts when managers can hedge. Journal of Financial Economics 97 218-238. https://doi.org/10.1016/j.jfineco.2010.03.015.

[41] Gervais, S., Heaton, J.B., Odean, T., 2011. Overconfidence, compensation contracts, and capital budgeting. Journal of Finance 66 , 1735-1777. https://doi.org/10.1111/j.1540-6261.2011.01686.x.

[42] Gervais, S., Goldstein, I., 2007. The positive effects of biased self- perceptions in firms. Review of Finance 11 , 453-496. https://doi.org/10.1093/rof/rfm022.

[43] Ghozali, I., \& Fuad, M. (2005). Structural Equation Modeling. Teori, Konsep dan Aplikasi dengan Program Lisrel, 8.

[44] Ghozali, Imam, 2013. Aplikasi Analisis Multivariat dengan Program IBM SPSS 21. Edisi 7, Penerbit Universitas Diponegoro, Semarang. Quarterly Journal of Economics 128, 1547-1584.

[45] Goel, A., Thakor, A., 2008. Overconfidence, CEO selection, and corporate governance. Journal of Finance 63, 2737-2784. https://doi.org/10.1111/j.1540-6261.2008.01412.x.

[46] Goetzmann, William N. and Massimo Massa, 2008, Disposition matters: Volume, volatility, and price impact of a behavioral bias, forthcoming Journal of Portfolio Management https://doi.org/10.3905/jpm.2008.701622

[47] Gompers, P., Ishii, J., Metrick, A., 2003. Corporate governance and equity prices. Quarterly Journal of Economics 118, 107-155. https://doi.org/10.1162/00335530360535162.

[48] Graham, J., Harvey, C., Puri, M., 2013. Managerial attitudes and corporate actions. Journal of Financial Economics 109, 103-121. https://doi.org/10.1016/j.jfineco.2013.01.010

[49] Graham, J., Harvey, C., Rajgopal, S., 2005. The economic implications of corporate financial reporting. Journal of Accounting and Economics 40, 3-73. https://doi.org/10.1016/j.jacceco.2005.01.002.

[50] Graham, J., Li, S., Qiu, J., 2012. Managerial attributes and executive compensation. Review of Financial Studies 25 , 144-186. https://doi.org/10.1093/rfs/hhr076.

[51] Greene, W. H., \& Schlacther, D. (2005). Econométrie (Vol. 5, No. 4). France: Pearson éducation.

[52] Grund, C., Sliwka, D., 2010. Evidence on performance pay and risk aversion. Economics Letters 102, 8-11. https://doi.org/10.1016/j.econlet.2009.09.005.

[53] Hackbarth, D., 2008. Managerial traits and capital structure decisions.

[54] Hackbarth, D., 2009. Determinants of corporate borrowing: a behavioral perspective. Journal of Corporate Finance 15, 389-411. https://doi.org/10.1016/j.jcorpfin.2009.02.001.

[55] Hall, B. J., \& Murphy, K. J. (2002). Stock options for undiversified executives. Journal of accounting and economics, 33(1), 3-42. https://doi.org/10.1016/S0165-4101(01)00050-7. 
[56] Hambrick, D. C., \& Mason, P. A. (1984). Upper echelons: The organization as a reflection of its top managers. Academy of management review, 9(2), 193-206.

[57] Hayes, R.M., Lemmon, M., Qiu, M., 2012. Stock options and managerial in- centives for risk taking: evidence from FAS 123R. Journal of Financial Economics 105, 174-190. https://doi.org/10.1016/j.jfineco.2012.01.004.

[58] Heaton, J., 2002. Managerial optimism and corporate finance. Financial Management 31, 33-45. https://doi.org/10.2307/3666221.

[59] Hersh Shefrin, Understanding behavioral finance and the psychology of investing, Oxford university press 2002. https://doi.org/10.1093/0195161211.001.0001.

[60] Hilary, G., Hsu, C., Segal, B., 2013. The bright side of managerial over- optimism. Unpublished working paper. INSEAD and Hong Kong University of Science and Technology.

[61] Hirshleifer, D., Low, A., Teoh, S., 2012. Are overconfident CEOs better innovators? Journal of Finance 67 1457-1498. https://doi.org/10.1111/j.1540-6261.2012.01753.x.

[62] Hitt, M. A., \& Tyler, B. B. (1991). Strategic decision models: Integrating different perspectives. Strategic management journal, 12(5), 327-351. https://doi.org/10.1002/smj.4250120502.

[63] Howell, D. C. (2007). Resampling statistics: randomization and the bootstrap. The University of Ver.

[64] Hribar, P., Yang, H., 2013. CEO overconfidence and management forecasting. Unpublished working paper. University of Iowa and Singapore Management University.

[65] Hribar, P., Yang, H., 2015 CEO Overconfidence and Management Forecasting. Contemporary Accounting ResearchVolume 33, Issue 1, Version of Record online: 12 JUN 2015.

[66] Huddart, S., Lang, M., 1996. Employee stock option exercises: an empirical analysis. Journal of Accounting and Economics 21, 5-43. https://doi.org/10.1016/01654101(95)00409-2.

[67] Hurlin, C., \& Venet, B. (2001). Granger causality tests in panel data models with fixed coefficients. Cahier de Recherche EURISCO, September, Université Paris IX Dauphine.

[68] Hutton, A. P., \& Stocken, P. C. (2009). Prior forecasting accuracy and investor reaction to management earnings forecasts. Available at SSRN 817108. https://doi.org/10.2139/ssrn.817108

[69] Januarti, I., \& Ghozali, I. (2013). Supervisor Power and Auditor Experience Influencing Auditor's Response. Research Journal of Finance and Accounting, 4(2), 8-18.

[70] Jared Harris, Philip Bromiley, Incentives to Cheat: The Influence of Executive Compensation and Firm Performance on Financial Misrepresentation, Page Range: 350 - 367, organization science.

[71] Jenter, D., 2005. Market timing and managerial portfolio decisions Journal of Finance 60, 1903-1949. https://doi.org/10.1111/j.15406261.2005.00783.x.

[72] Johnson, Neil F., Jefferies, Paul, Hui, Pak Ming, Financial market complexity, working paper.

[73] Judith Chevalier And Glenn Ellison, Are Some Mutual Fund Managers Better Than Others? Cross-Sectional Patterns in Behavior and Performance, The Journal Of Finance • vol. liv, no. 3 • june 1999.

[74] Kaplan, S., Klebanov, M., Sorensen, M., 2012. Which CEO characteristics and abilities matter? Journal of Finance 67, 973-1007. https://doi.org/10.1111/j.15406261.2012.01739.x.

[75] Keiber, K., 2005. Managerial compensation contracts and overconfidence. Unpublished working paper. EuropaUniversität Viadrina Frankfurt (Oder).

[76] Kochhar, R., \& David, P. (1996). Institutional investors and firm innovation: A test of competing hypotheses. Strategic Management Journal, 17(1), 73-84. https://doi.org/10.1002/(SICI)10970266(199601)17:1<73::AID-SMJ795>3.0.CO;2-N

[77] Kolasinski, A.C., Li, X. Forthcoming. Can Strong Boards and Trading Their Own Firm's Stock Help CEOs Make Better Decisions? Evidence from Acquisitions by Overconfident CEOs. Journal of Financial and Quantitative Analysis. https://doi.org/10.1017/s0022109013000392.

[78] Landier, A., Thesmar, D., 2009. Financial contracting with optimistic entrepreneurs. Review of Financial Studies 22, 117-150. https://doi.org/10.1093/rfs/hhn065.

[79] Larwood, L., Whittaker, W., 1977. Managerial myopia: self-serving biases in organizational planning. Journal of Applied Psychology 62, 194-198. https://doi.org/10.1037/0021-9010.62.2.194.

[80] Lee, P. M., \& O'neill, H. M. (2003). Ownership structures and R\&D investments of US and Japanese firms: Agency and steward- ship perspectives. Academy of Management Journal, 46(2), 212 225. https://doi.org/10.2307/30040615.

[81] Lucian Arye Bebchuk Jesse M. Fried David I. Walker," Manageria power and rent extraction in the design of executive compensation", ISSN 1045-6333, Discussion Paper No. 366 06/2002.

[82] Malcolm Baker, Xin Pan, Jeffrey Wurgler, 2009. A Reference Point Theory of Mergers and Acquisitions, December 2009,NBER Working Paper No. w15551.

[83] Malcolm Baker, Xin Pan, Jeffrey Wurgler, 2012. The effect of reference point prices on mergers and acquisitions. Journal of Finan$\begin{array}{llll}\text { cial } & \text { Economics } & 106 & \text { (2012) 49-71. }\end{array}$ https://doi.org/10.1016/j.jfineco.2012.04.010.

[84] Malmendier, U., Tate, G., 2005a. CEO overconfidence and corporate investment. Journal of Finance 60, 2661-2700. https://doi.org/10.1111/j.1540-6261.2005.00813.x.

[85] Malmendier, U., Tate, G., 2005b. Does overconfidence affect corporate investment? CEO overconfidence measures revisited. European Financial Management 11, 649-659. https://doi.org/10.1111/j.1354-7798.2005.00302.x.

[86] Malmendier, U., Tate, G., 2008. Who makes acquisitions? CEO over- confidence and the market's reaction. Journal of Financial Economics 89, 20-43. https://doi.org/10.1016/j.jfineco.2007.07.002.

[87] Malmendier, U., Tate, G., Yan, J., 2011. Overconfidence and early-life experiences: the impact of managerial traits on corporate financial policies. Journal of Finance 66 1687-1733. https://doi.org/10.1111/j.1540-6261.2011.01685.x.

[88] MarkHumphery-Jenner, LingLeiLisic,VikramNanda, SabatinoDinoSilveri, Executive overconfidence and compensation structure, Journal ofFinancialEconomics000(2016)1-26 .

[89] Matsunaga, S. R., \& Yeung, P. E. (2008, October). Evidence on the impact of a CEO's financial experience on the quality of the firm's financial reports and disclosures. AAA.

[90] Matsunaga, S., Park, C., 2001. The effect of missing a quarterly earnings. Journal of Financial and Quantitative Analysis 43, 843-881.

[91] Merle Erickson,Michelle Hanlon,Edward L. Maydew, Is There a Link between Executive Equity Incentives and Accounting Fraud? Journal of Accounting Research,Vol. 44 No. 1 March 2006 https://doi.org/10.1111/j.1475-679X.2006.00194.x.

[92] Nezih Guner, Gustavo Ventura,Yi Xu d, Macroeconomic implications of size-dependent policies, Review of Economic Dynamics 11 (2008) 721-744. https://doi.org/10.1016/i.red.2008.01.005.

[93] Oyer, P., Schaefer, S., 2005. Why do some firms give stock options to all employees? An empirical examination of alternative theories. Journal of Financial Economics 76 , 99-133. https://doi.org/10.1016/j.jfineco.2004.03.004.

[94] Paquerot, M. (1996). L'enracinement des dirigeants et ses effets. Revue française de gestion, (111), 212-225.

[95] Puri, M., Robinson, D., 2007. Optimism and economic choice. Journal of Financial Economics 86, 71-99. https://doi.org/10.1016/j.jfineco.2006.09.003.

[96] Rajan, R. G., \& Zingales, L. (1995). What do we know about capital structure? Some evidence from international data. The journal of Finance, 50(5), 1421-1460. https://doi.org/10.1111/j.15406261.1995.tb05184.x.

[97] Randall Morck, Andrei Shleifer and Robert W. Vishny, Management Ownership and Market Valuation, Journal of Financial Eco$\begin{array}{llll}\text { nomics } & 20 & \text { (1988) 293-315. North-Holland }\end{array}$ https://doi.org/10.1016/0304-405X(88)90048-7.

[98] Robert Libby, Kristina Rennekamp, 2012. Self-Serving Attribution Bias, Overconfidence and the Issuance of Management Forecasts. Journal of Accounting Research Volume 50, Issue 1, March 2012, Pages 197-231. https://doi.org/10.1111/j.1475-679X.2011.00430.x.

[99] Roll, R., 1986. The hubris hypothesis of corporate takeovers. Journal of Business 59, 197-216. https://doi.org/10.1086/296325.

[100] Ronald w. Masulis, shawn mobbs, Are all inside directors the same? evidence from the external directorship market,Journal of Finance, View issue TOC Volume 66, Issue 3 June 2011 Pages 823-872.

[101] Rose, N. L., \& Shepard, A. (1994). Firm diversification and CEO compensation: Managerial ability or executive entrenchment? (No. w4723). National Bureau of Economic Research. https://doi.org/10.3386/w4723.

[102] Ryan Jr, H. E., \& Wiggins III, R. A. (2002). The interactions between R\&D investment decisions and compensation policy. Financial Management, 5-29. https://doi.org/10.2307/3666319.

[103] Sautner, Z., Weber, M., 2009. How do managers behave in stock option plans? Clinical evidence from exer- 
cise and survey data. Journal of Financial Research 32, 123-155. https://doi.org/10.1111/j.1475-6803.2009.01245.x.

[104] Sautner, Z., Weber, M., Glaser, M., 2010. What determines how top managers value their stock options? Unpublished working paper. Frankfurt School of Finance \& Management, University of Mannheim, and LudwigMaximilians-University Munich.

[105] Schrand, C.M., and S.L.C. Zechman, 2010, Executive overconfidence and the slippery slope to fraud, working paper, University of Pennsylvania and University of Chicago.

[106] Simi Kedia, Thomas Philippon, the Economics of Fraudulent Accounting, the Review of Financial Studies, Volume 22 Issue 6 June 2009

[107] Skantz, T.R., 2012. CEO pay, managerial power, and SFAS 123(R). The Accounting Review 87, 2151-2179. https://doi.org/10.2308/accr-50224.

[108] Soojin Yim, The acquisitiveness of youth: CEO age and acquisition behavior, Journal of Financial Economics 108 (2013) 250273. https://doi.org/10.1016/j.jfineco.2012.11.003.

[109] Taylor, S., Brown, J., 1988. Illusion and well-being: a social psychological perspective on mental health. Psychological Bulletin 103, 193-210. https://doi.org/10.1037/00332909.103.2.193.

[110] Titman, S., \& Wessels, R. (1988). The determinants of capital structure choice. The Journal of finance, 43(1), 1-19. https://doi.org/10.1111/j.1540-6261.1988.tb02585.x.

[111] Tylecote, A., \& Ramirez, P. (2006). Corporate governance and innovation: The UK compared with the US and 'insider'economies. Research Policy, 35(1), 160-180. https://doi.org/10.1016/j.respol.2005.09.004.

[112] Van den Steen, E. (2005). Organizational beliefs and managerial vision. Journal of Law, Economics, and organization, 21(1), 256283. https://doi.org/10.1093/jleo/ewi011.

[113] Walsh, J. P., Henderson, C. M., \& Deighton, J. (1988). Negotiated belief structures and decision performance: An empirical investigation. Organizational Behavior and Human Decision Processes, 42(2), 194-216. $\quad$ https://doi.org/10.1016/07495978(88)90012-X.

[114] Yael v. Hochberg, alexander ljungqvist, and Yang lu, Whom You Know Matters: Venture Capital Networks and Investment Performance, the Journal of finance • vol. 1xii, no. 1 • february 2007. 